ond World War supports the conclusion that consent of the subject was a primary consideration in research with humans, at least by 1900 . For example, medicine's leading spokesperson on ethics at the time, William Osler, wrote in 1907 that the "full consent" of the research subject was "an ethical requirement". He also argued that although the ultimate test of a new procedure is to try it on humans, that should never be done "before it has been tried on animals". Although the importance that early-twentieth-century researchers attached to consent is well documented in the book, Lederer spends most of her time on her thesis that groups opposed to experiments on animals were the most influential in attacking and limiting experiments on human beings.

At that time, research on both animals and humans was denoted and denounced simply as "vivisection". The most famous essay against the practice was written by George Bernard Shaw in his preface to The Doctor's Dilemma. Shaw saw vivisection as simple cruelty that was uncritically justified by the search for knowledge that he believed could be obtained in less barbaric ways. In the United States the groups fighting animal vivisection argued that unless it was prohibited, scientists would quickly move on to human experimentation. Protection of animals was therefore seen not only as a good in itself, but as a way to protect humans from unscrupulous scientists as well. The fact that many human experiments were carried out on orphans and institutionalized mental patients helps to explain the early alliances between animal-protection organizations (humane societies) and child-welfare organizations.

The author's description of experimentation on children and animals before the Second World War is much more complete than her analysis of research on prisoners and members of the military, although those wanting to do their own research on these populations will find places to begin in the book. Her analysis of the legal cases, however, leaves much to be desired. She does discuss the most famous pre-war US case to reach an appeals court, that of Bonner v. Moran in which a 15-year-old boy was recruited to try to graft some of his skin to a burned relative by keeping it attached to his circulation (through a "tube of flesh") while the graft was attached to the relative. The author says this case is consistent with the general pre-war US view that physicians experimented on patients at their own peril, being held liable for "adverse results". In fact, the case supports the proposition that reasonable experimentation on mature minors such as Bonner is lawful so long as the informed consent of both the minor and the parents is obtained. That is still the law today.

The antivivisection movement to pro- tect animals lost much of its momentum during the First World War. Since the Second World War, human experimentation has moved from single researchers working on one or a few subjects to largescale research projects often funded by government and commercial ventures. The promises of advancing knowledge and conquering disease remain, but the public has become much more supportive of the venture, usually uncritically so. Even in this new atmosphere of public support and enthusiasm, however, the protection of the rights and welfare of human subjects has remained a central concern of society, and a new 'animal rights' movement has arisen that once again condemns gratuitous cruelty to sentient creatures. Those interested in the historical interplay of animal-rights activists and human experimentation will profit from reading this book. Those with a broader interest in human experiments before the Second World War will find it less illuminating. All readers, however, would probably agree with the observation made at the turn of the century by the antivivisectionist Albert Leffingwell: "There is no objection to human experimentation when there is no invasion of human rights".

George J. Annas is in the Department of Health Law, Boston University Schools of Medicine and Public Health, 80 East Concord Street, Boston, Massachusetts 02118, USA.

\section{No sympathy for the Devil}

\section{Mark Pagel}

The Lucifer Principle: A Scientific Expedition into the Forces of History. By Howard Bloom. Atlantic Monthly: 1995. Pp. 466. \$24.

WHAT little is known of Lucifer's life comes from just a few fragments spoken about him by others, including God. Lucifer left no written work. We do know Lucifer was an angel, but that this career was abruptly terminated. God had to cast him out of heaven for organizing a rebellion among the angels and for stealing light. With what would be irritating consequences for the rest of us, Lucifer landed somewhere below Earth where God had little control over him (Machiavelli would never have made this mistake). This all happened sometime before Adam and Eve. Despite the paucity of information about the man, however, most are familiar with his oeuvre.

In Lucifer, writers throughout the ages have found a convenient metaphor for the evil tendencies that possess human nature. Sociobiology has recently provided a mechanism for this possession: aeons of natural selection have favoured strategies that promote our selfish genetic interests. Although a powerful creative force, natural selection has left us masters at lying, cheating, coveting, stealing, pillaging, raping and murdering. These things are part of the normal routine for the merely infra-human but become evil when expressed in ourselves - presumably because we fear our own worst instincts.

Against this backdrop of the Luciferpossessed individual, Howard Bloom, a sometime rock-impresario and sometime researcher, constructs the view that humans are nevertheless ineluctably part of a larger social being - the superorganism - for whose ends we will sometimes behave. Superorganisms arise when individuals surrender their own interests to those of a larger group. To Bloom, the cells of a tree, the ants in a colony, the bees in a nest and the humans in a social group act as one, and thereby constitute superorganisms. When it suits the superorganism that we call society, we will wage war on its behalf or even commit suicide when we feel it no longer wants or needs us. Our most terrifying capacities for violence and destruction arise out of our subjugation to the superorganism.

Many of Bloom's arguments will elicit a sense of déjà $v u$ to evolutionary biologists, who long ago abandoned the idea that individuals sacrifice their interests to those of a group. One of the great triumphs of evolutionary thinking has been to show how the selfish interests of individuals often coincide with those of the group. Indeed, that may be why the group exists. The peculiar form of genetic inheritance among ants, bees and wasps known as haplo-diploidy means that nonreproductive workers can actually reap higher fitness from rearing their sisters than from reproducing themselves. In other cases, behaviours such as the giving of an alarm call at the approach of a predator, only seem to be for the good of the group. On closer inspection, these alarm calls are shamelessly selfish: they tend either to be given only when relatives are around or to direct attention away from the caller and towards the other (unrelated) fleeing members of the group.

Reproductively inefficient behaviours such as suicide and celibacy may not be performed to advance the group's interests. Bloom uses 'apoptosis' or programmed cell death to understand human suicide. The cells of many multicellular organisms have suicide programmes. When a cell in such an organism no longer receives the message to stay alive, it uncomplainingly activates its death programme and dies. In doing so it probably promotes its genetic interests because the other cells in the organism are clones of it: 
the interests of the individual and the group coincide. But it is doubtful whether people commit suicide or give up reproduction to promote a societal superorganism. Human tendencies towards suicide and celibacy could have some ancient basis in promoting one's immediate relatives, if by these actions the relatives are substantially better off. The conditions for this are probably rare and so it should not be surprising that suicide, notwithstanding Jim Jones's obedient followers and the fabled Japanese warriors of the Second World War, is also rare. So is celibacy: America's Shakers - a sect of religious celibates - are on the verge of extinction.

The human capacity for warfare does, on the other hand, deserve some consideration, if only because it is so common and because so many participate in it. Warfare among human tribal societies may have made good genetic sense to individuals if the members of one's own group tended to be closely related. Vast numbers of Crusaders went into battle with little protection beyond the crosses on their chests, and vast numbers died. These men were not necessarily related. But most lived the abject life of a serf, and so promises of salvation and riches may have made crusading seem an even bet. In a contemporary setting, atavistic and utterly repugnant tendencies such as football hooliganism may not so much constitute surrendering of our selfish needs to those of the group, but rather the distasteful expression of them writ large in possibly inappropriate circumstances. But how do we explain contemporary grown-up warfare in which lots of people regularly die? Here it may again pay to examine the influences of poverty, coercion and punishment as much as any role of the superorganism. Few soldiers with other options willingly go to their deaths.

Not many evolutionary biologists would feel qualified to write a book that touches on most things from apoptosis to neural nets to Erasmus Darwin's Zoonomia. Fewer still would see a common thread the Lucifer Principle - linking all these topics to a dark side of human nature. Even fewer would have the courage, as does Bloom, to hold the view that this insight could prevent the decline of the United States in the closing years of the twentieth century. In Nietzsche's Thus Spake Zarathustra, the "last man" discovers happiness through rationality. But Nietzsche found this happi-ness contemptible because it was based on a naive optimism that celebrated rationality (science) as the technique for the mastery of life and the discovery of human values.

Mark Pagel is in the BBSRC-NERC Ecology and Behaviour Group, Department of Zoology, University of Oxford, South Parks Road, Oxford OX1 3PS, UK.

\section{Sailing the ship of Down}

\author{
Phillip R. Sloan
}

Charles Darwin: Voyaging, Volume 1 of a Blography. By Janet Browne. Knopf/Cape: 1995. Pp. 606. \$35, £25.

THE historian of science I. Bernard Cohen once described the "three revelations" of Isaac Newton, as researchers first digested his printed works, then his correspondence and some of his unpublished manuscripts and finally the more recently available archive of unpublished
Peter Brent (1981), Peter Bowler (1990), John Bowlby (1990) and most recently the highly praised study by Adrian Desmond and James Moore (1991), surely alters some basic assumptions about Darwin and his revolution that had prevailed since the Victorian Life and Letters and the Autobiography. Yet the basic plot of Darwin's life and the cast of characters has remained surprisingly constant. There have been strikingly few truly astounding revelations and no closet manuscripts have come to light to reveal a very different mind at work than one would have expected from the Origin, Descent or the rest of the printed corpus. Nor have we yet found evidence of secret lovers or other titillating details of Darwin's

\section{IMAGE UNAVAILABLE FOR COPYRIGHT REASONS}

The traditional ceremony of 'crossing the line', drawn by Augustus Earle, the Beag/e's artist. From Captain Robert R. FitzRoy's Narrative, 1839.

material. Through these layers of scholarly inquiry, the image of Newton as the archetypal rationalist of the Principia was replaced by the Newton of the prophecies of the Book of Daniel and the "Queries" to the Opticks, and ultimately by the esoteric alchemist in search of the "Greene Lyon".

The potential for a similar transformation in our understanding of Charles Darwin has existed since 1959 when the full archive of his manuscripts and letters became available. The heroic efforts of the notebooks and correspondence projects have drawn together a remarkable body of information. Darwin promises to become the most completely documented scientist in recorded history. But who is the Darwin of this third revelation?

The run of biographies and partial biographies that has accompanied this new archival scholarship, beginning with Gertrude Himmelfarb's Darwin and the Darwinian Revolution of 1959 through to the studies of Edward Manier (1978), private life.

The mysteries and gaps in our understanding of his scientific thought still need clear explanations. When and why did he first think of transformism? What were the reasons for his refusing to publish details of his theory in 1844 ? Why were barnacles worth so much of his time and effort? Something more modest has instead been attained: the assemblage of a vast amount of material for describing in remarkable detail the intimate picture of the life and times of a largely conventional Victorian intellectual living through a period of dramatic social and scientific change.

Yet we still do not really have a true 'scientific' biography of the genre represented by the classic works of Richard Westfall on Newton, Thomas Hankins on Jean D'Alembert and William Rowan Hamilton, and Pearce Williams on Faraday, in which the science is brought to life by the use of personal biography. The problem may have been made more diffi- 